\title{
Традиции Ильи Ильфа и Евгения Петрова и Компромисс Сергея Довлатова
}

\author{
Traditions of Ilya Ilf and Yevgeny Petrov \\ and Compromise of Sergey Dovlatov
}

\begin{abstract}
The aim of the study is to investigate common motifs, characters, metaphors and plots in Sergey Dovlatov's Compromise and Ilya Ilf and Yevgeny Petrov's novels The Twelve Chairs and The Little Golden Calf using the structural and comparative-historical methods. In this case study Compromise is treated as the text, in which Dovlatov determines the underlying principle for reading the short stories contained in his Compromise collection in the context of the novels The Twelve Chairs and The Little Golden Calf by Ilf and Petrov. The results of the research are confirmed by the contextual study of Dovlatov's correspondence. This allows us to state that the novels of Ilf and Petrov are the subtext of Sergei Dovlatov's work. The article opens totally new and inspiring directions of Dovlatov studies, since no other scholars have ever turned their attention to the relationships between Dovlatov's works and the traditions of Ilf and Petrov.
\end{abstract}

Keywords: Ilf, Petrov, Dovlatov, plot, metaphors, motives

Светлана Зайцева, Московский государственный лингвистический университет, Москва Россия, sveta_gallery@mail.ru, ORCID ID: https://orcid.org/0000-0002-4720-0873

За восемь лет до рождения Сергея Довлатова Виктор Борисович Шкловский в статье Юго-Запад (1933) назвал Илью Ильфа и Евгения Петрова лидерами „южнорусской школы” и предрек сюжетному направлению в русской литературе блестящую будущность (Šklovskij 470-474). Многие годы Довлатов числился студентом-филологом Ленинградского университета (изучал финский язык) и, несомненно, был знаком с работами Шкловского. Ср.: „Чем объясняется факт идентичных литературных сюжетов у разных народов? По Шкловскому - самопроизвольным их возникновением. [...] Писатель [...] улавливает сигналы. Чувствительность к такого рода сигналам и есть Божий дар" (Dovlatov 2003: 205). На Шкловского обрушился шквал критики, но его прогнозы сбылись. В статье Современная повесть и юмор (1967) Александр Павлович и Мариэтта Омаровна Чудаковы возводили истоки молодежной 
прозы оттепельного периода, тесно связанной с „отрицанием прежней фразеологии”, к романам Ильфа и Петрова (Čudakovy 222-232).

Культовый статус и рецепция романной дилогии Двенадцать стульев (1928) и Золотой теленок (1931) в творчестве современников и потомков Ильфа и Петрова пока еще не получили достаточного освещения в научной литературе. В электронной базе Российской государственной библиотеки зарегистрировано всего восемь диссертаций, связанных с творчеством Ильфа и Петрова. Основными работами остаются монографии 60-х годов Бориса Ефимовича Галанова, Лидии Марковны Яновской (Galanov; Ânovskaâ) и классические труды Юрия Константиновича Щеглова (Ŝeglov).

В свое время Сергей Гандлевский выявил „следы” Ильфа и Петрова в произведениях Владимира Владимировича Набокова (Gandlevskij), позднее Наталья Ильинична Фаликова нашла их в прозе Константина Вагинова, о чем был сделан доклад К. Вагинов как советский писатель: проблема новой идентичности в авантюрном романе "Бамбочада" (Falikova).

Но до сих пор нет исследований о влиянии „бендерианы” на творчество Довлатова, не говоря уже о посреднической роли Ильфа и Петрова в передаче традиций Николая Гоголя, Федора Достоевского и Антона Чехова. В настоящей статье мы постараемся продемонстрировать глубокую укорененность поэтики Довлатова в творчестве Ильфа и Петрова и отражение этой связи в книге Довлатова Компромисс $(1981,1989)$, как на мотивном, так и на композиционном уровне.

Компромисс имеет сложную жанровую природу и непростую историю создания (см. Dovlatov 2016а:220). О Компромиссе писали как отечественные, так и зарубежные исследователи (Gudman; Rosenberg). Отдельно следует сказать о работе Алексей Светланович Семененко Л. Пейпс как зеркало советской действительности, или О методе Сергея Довлатова, в которой проанализирован Компромисс восьмой (Semenenko).

В окончательном виде Компромисс - конструкция из двенадцати новелл с обрамляющим сюжетом, изложенным в авторском вступлении. Словно по рецепту формалистов в изложении Бориса Викторовича Томашевского (см. Tomaševskij) Довлатов собирает повесть из отдельных рассказов: Компромисс в равной степени можно назвать и сборником рассказов, и повестью.

Книга отражает эстонский период жизни автора (с сентября 1972 по март 1975 г.) и содержит отрывки из его (и чужих) газетных публикаций в эстонской прессе этого времени. Каждый из отрывков дополняется новеллой об обстоятельствах возникновения этой публикации. Рассказы писались и частично печатались (под отдельным заголовком и без газетной преамбулы) с 1973 по 1980 г., то есть и в эстонский период, и после отъезда писателя из Эстонии, и после его эмиграции из СССР в 1978 г. Первоначально Довлатов 
планировал составить Компромисс из шести рассказов, но в 1981 г. вышла книга, содержащая одиннадцать „компромиссов” (так называются рассказы-главы в книге). В 1984 г. был написан рассказ Лишний, а в 1989 г. он вошел на правах Компромисса десятого в окончательный текст, содержащий двенадцать „компромиссов”.

Пожалуй, именно включение двенадцатого „компромисса” наиболее явно обозначило связь произведения с Двенадцатью стульями и Золотым Теленком, поскольку иных подсказок Довлатов читателю не оставил. Насколько такая игра характерна для довлатовской поэтики, показывает, например, и то, что ни в одном из рассказов ни одна из сюжетных ситуаций не обозначена прямо словом „компромисс”: являясь основной темой книги, идея компромисса нигде не проявляет себя лексически - в виде прямой номинации. Именно крайний лаконизм и органическая неспособность Довлатова повторять трюизмы и общие места способствовали тому, что он практически нигде не выражает своего несомненного интереса к знаменитым сатирикам 20-30-х годов. Но „обмолвки” его существенны. Так, в Соло на IBM (1990) Довлатов замечает:

Существует понятие „чувство юмора”. Однако есть и [...] „чувство драмы”. Отсутствие чувства юмора [...] катастрофа. Но и отсутствие чувства драмы - такая же беда. Лишь Ильф с Петровым умудрились написать хорошие романы без тени драматизма (Dovlatov 2003: 207).

Казалось бы, отсутствие драматизма должно рассматриваться в этом контексте как недостаток романов Ильфа и Петрова, но Довлатов делает для них исключение. И в этом есть определенная логика. Еще в период армейской службы, комментируя пробы своего пера, Довлатов признавался отцу:

Ты обратил внимание на то, что о разных страшных вещах говорится спокойно и весело. Я рад, что ты это заметил. Это очень характерная для нас вещь (Dovlatov 1999a: 29).

Умение писать о „страшных вещах” „спокойно и весело” (ср. „без драматизма") может отражать увлечение юного Довлатова прозой Михаила Александровича Шолохова и Исаака Бабеля. Позднее ориентиры сменились, Довлатов открыл для себя „чувство драмы”, но не стал его абсолютизировать, а в письме к Людмиле Яковлевне Штерн от 8 июня 1979 г., описывая открытие газеты „Новый американец”, воспользовался системой персонажей Золотого теленка для характеристики своей команды:

Мои товарищи и коллеги - прелесть. Расскажу о них коротко. Боря Меттер - Остап, командор. Женя Рубин - Паниковский, я - Шура Балаганов. <Алексей> Орлов - Адам Козлевич. И „,антилопа” есть. Все, кроме меня, умеренно и охотно пьющие. Все рослые и толстые. Широкие и веселые... (Dovlatov 2017: 321). 
Письмо к Штерн было написано в период, когда основной состав Компромисса уже сформировался и книга готовилась к публикации („Новый американец" выходил с февраля 1980 г. по март 1982 г.). Характерно и то, что работа журналистов как таковая ассоциируется у Довлатова с деятельностью „великого комбинатора”.

Как мы уже отметили, вторая редакция Компромисса (1989) - это конструкция из двенадцати новелл, объединенных сквозными героями и обрамляющим введением, нечто среднее (NB: компромисс) между сборником рассказов и повестью. Однако и дебютный роман Ильфа и Петрова имел схожее членение фабулы, заданное числом разыскиваемых стульев. Известно, что Шкловский сравнил фабулу Двенадиати стульев с фабулой Шести Наполеонов Артура Конана Дойла (Šklovskij 473). В первоначальном замысле книги Довлатова также предполагалось шесть частей (сказалась ли в этом сознательная тяга к символической шестикратности, обозначающей традицию, сказать затруднительно). Каждый из стульев был связан со своим владельцем, что давало повод для знакомства с ними и создания портретной галереи персонажей по типу Mepmвых душ Гоголя. Обыгрывается у Довлатова и мотив „Золотого тельца”, поскольку ценность корреспонденции определяется полученным за нее гонораром [ср. „Начнем с копеечной газетной информации" (Dovlatov 2016a: 8)].

В карнавальном плутовском мире Остапа Бендера проверке и отчасти осмеянию подвергается понятие истины. Бухгалтер Берлага, от которого Бендер и его команда получают важную информацию, заявляет (гл. $18 \mathrm{Ha}$ суше и на море): „Я сделал это не в интересах истины, а в интересах правды” (Il'f, Petrov 1933: 31). Думается, не случайно эта оппозиция попала в одну из статей Довлатова в „Новом американце”, а также в интродукцию книги Компромисс:

Трудна дорога от правды к истине. В один ручей нельзя ступить дважды. Но можно сквозь толщу воды различить усеянное консервными банками дно. А за пышными театральными декорациями увидеть кирпичную стену, веревки, огнетушитель и хмельных работяг. Это известно всем, кто хоть раз побывал за кулисами... (Dovlatov 2016а: 8).

В сложной и развернутой метафоре этого вступительного абзаца оказываются сконцентрированы мотивы целого ряда образных рядов, образующих смысловую структуру книги Довлатова: здесь и проблемы истинности-ложности, и гидронимические метафоры, и театральные образы, характерные для травестийных плутовских сюжетов. Так, в первом томе дилогии (гл. XXXIII В mеатре Колумба) Остап обнажает театральную сторону своих талантов: 
Помните, Воробьянинов, наступает последний акт комедии Сокровище моей тещи. Приближается финита-ла-комедия, Воробьянинов! Не дышите, мой старый друг! Равнение на рампу! О, моя молодость! О, запах кулис! Сколько воспоминаний! Сколько интриг! Сколько таланту я показал в свое время в роли Гамлета!.. Одним словом - заседание продолжается (Il'f, Petrov 1997: 399).

Именно Остап Бендер, путешествующий, терпящий нужду, добывающий нужные ему сведения, изменчивый как Протей и покоряющий всех, с кем его сводит судьба (особенно женщин), является душой дилогии Ильфа и Петрова. Его яркая портретная характеристика - незабываемая часть этого образа:

В половине двенадцатого с северо-запада, со стороны деревни Чмаровки, в Старгород вошел молодой человек лет двадцати восьми. За ним бежал беспризорный. [...] В город молодой человек вошел в зеленом, узком, в талию, костюме. Его могучая шея была несколько раз обернута старым шерстяным шарфом, ноги были в лаковых штиблетах с замшевым верхом апельсинного цвета. Носков под штиблетами не было. В руке молодой человек держал астролябию (Il'f, Petrov 1997: 46).

Очень схожий внешне герой был введен Довлатовым во вторую редакцию Компромисса. Исходное название рассказа Лишний напоминает нам о „лишнем человеке”, к чьей категории в советском контексте, несомненно, следует отнести и Остапа Бендера (что и вообще характерно для героя плутовского типа, по мнению Михаила Михайловича Бахтина). Современные Ильфу и Петрову критики Федор Васильевич Гладков (B чем опасность) и Сергей Борисович Ингулов видели опасность „в склонности некоторых литераторов живописать так называемых лишних людей современности" (Odesskij, Fel'dman 183). В Компромиссе десятом мы знакомимся с Эрнстом Бушем:

С продавленного дивана встал мужчина лет тридцати. У него было смуглое мужественное лицо американского киногероя. Лацкан добротного заграничного пиджака был украшен гвоздикой. Полуботинки сверкали. [...] В Буше имелось то, что роковым образом действует на стареющих женщин. А именно - бедность, красота, саркастический юмор, но главное - полное отсутствие характера. За два года Буш обольстил четырех стареющих женщин. Галина Аркадьевна была пятой и самой любимой. Остальные сохранили к Бушу чувство признательности и восхищения. Злые языки называли Буша альфонсом. Это было не справедливо. В любви к стареющим женщинам он руководствовался мотивами альтруистического порядка. Буш милостиво разрешал им обрушивать на себя водопады горьких запоздалых эмоций (Dovlatov 2016a: 140, 143).

Буш не полностью воспроизводит тип Бендера, но последний, как мы помним, нередко испытывал свои чары на женщинах старше себя, в частности - на мадам Грицацуевой: „Молодая была уже не молода. [...] Но- 
вого мужа она обожала и очень боялась. Поэтому звала его [...] товарищ Бендер" (Il'f, Petrov 1997: 107). Буш воплощает в себе концентрированное влияние Ильфа и Петрова, поскольку воспроизводит не только тип Бендера, но и других ярких представителей его команды. Так, под влиянием голода в нем просыпаются черты „гусекрада” Михаила Самуэлевича Паниковского (Золотой теленок):

- Бендер, - захрипел он вдруг, - вы знаете, как я вас уважаю, но вы ничего не понимаете! Вы не знаете, что такое гусь! Ах, как я люблю эту птицу! Это дивная жирная птица, честное, благородное слово. Гусь! Бендер! Крылышко! Шейка! Ножка! Вы знаете, Бендер, как я ловлю гуся? Я убиваю его, как тореадор, - одним ударом. Это опера, когда я иду на гуся! „Кармен”!.. (Il'f, Petrov 1933: 322).

Сравним с описанием скитаний Буша по таллинскому парку Кадриорг, где он знакомится с Галиной. Увидев плавающих в пруду лебедей, Буш становится похожим на Паниковского; даже мысли его становятся отрывистыми, как речь „гусекрада”:

Мысли его становились все короче: „....Лебедь... Птица... Дичь...” [...] Он замер, как сеттер на болоте [...] Ощипанный лебедь может вполне сойти за гуся. А с целым гусем Буш не пропадет. В любой компании будет желанным гостем... Буш преобразился. В глубине его души звучал охотничий рожок. Он чувствовал, как тверд его небритый подбородок (Dovlatov 2016a: 156-158).

В Буше откликается и тип фанатичного антисоветчика Полесова, не способного поверить ни в какие достижения новой власти:

Как же большевики будут воевать? Чем? Сормовские заводы делают не танки, а барахло! Чем они будут воевать? Старыми винтовками? А воздушный флот? [...] Да-а... Довели большевички до ручки... (Il'f, Petrov 1997: 135).

Антисоветский нигилизм доведен в Эрнсте Буше до абсурдных пределов:

Буш отрицал саму историческую реальность. В частности - победу над фашистской Германией. Он твердил, что бесплатной медицины не существует. Делился сомнениями относительно нашего приоритета в космосе. После третьей рюмки Буш выкрикивал: Гагарин в космос не летал! [...] А все советские ракеты - это огромные консервные банки, наполненные глиной... (Dovlatov 2016а: 143).

Эрнест Буш концентрирует в себе целый спектр „ильфо-петровских” черт. Первоначальное название довлатовского рассказа Лииний имеет фразеологический аналог у Ильфа и Петрова, закрепившийся в виде крылатого выражения: „Эх, Киса, - сказал Остап, - мы чужие на этом празднике жиз- 
ни”. Фраза Остапа почти без изменений перекочевала в роман из дневника Ильи Ильфа о пребывании в Пятигорске в июне 1927 г.: „На празднике жизни в Пятигорске мы чувствовали себя совершенно чужими” (Il'f 134). 2 октября 1984 г. Довлатов писал Игорю Марковичу Ефимову:

В связи с Вашим возможным намерением издать в 86-87 году том моих рассказов, сообщаю, что я написал огромный рассказ под названием Лишний - старая тема ,лишнего человека": Онегин, Печорин, Григорий Мелехов, Остап Бендер... Не хотелось бы, чтоб она заглохла. Пока что я отослал рассказ Владимову в „Грани”, посмотрим, что он скажет. [...] Старший Серман довольно энергично его похвалил (Efimov 315 ).

Может сложиться впечатление, что влияние Ильфа и Петрова на Довлатова и ограничивается своеобразной стилизацией в Компромиссе десятом. Но это не так. В действительности, уже в первой редакции Компромисса просматривалось влияние авантюрной стихии дилогии Ильфа и Петрова, а к числу „лишних” героев, несомненно, относится и сам герой-рассказчик. С Бендером его сближает, в частности, мечтательность. В Двенадцати стульях о проектах Бендера сказано так:

Его проекты были грандиозны. Не то заграждение Голубого Нила плотиной, не то открытие игорного особняка в Риге с филиалами во всех лимитрофах (Il'f, Petrov 1991: 263).

Мечты автобиографического героя Довлатова скромнее, но так же несбыточны. Вот что мы находим в Компромиссе третьем:

- А правда, что все журналисты мечтают написать роман?

- Нет, - солгал я (Dovlatov 2016a: 17).

О крушении мечты главного героя повести мы узнаем в том же Компромиссе десятом, где появляется Эрнст Буш. Таким образом, отсвет Бендера лежит в этом „компромиссе”, как минимум, на двух персонажах сразу:

А тут еще начались в Эстонии политические беспорядки. Группа диссидентов обратилась с петицией к Вальдхайму. Потребовали демократизации и самоопределения. Через три дня их меморандум передавало западное радио. Еще через неделю из Москвы последовала директива - усилить воспитательную работу. [...] Завхоз Мелешко говорил в редакции:

- Могли обратиться к собственному начальству! Выдумали еще какого-то Хайма...

Я был подходящим человеком для репрессий. И меня уволили. Одновременно в типографии был уничтожен почти готовый сборник моих рассказов. И все это для того, чтобы рапортовать кремлевским боссам - меры приняты.

Конечно, я был не единственной жертвой. В эти же дни закрыли ипподром - рассадник буржуазных настроений (Dovlatov 2016a: 176).

Примечательно, что упоминания о мечте в Компромиссе третьем и Компромиссе десятом связаны с фамилией Мелешко; в обоих случаях ее носит 
задающий вопросы наивный персонаж, но в одном случае это Алла Мелешко, в другом - ее однофамилец завхоз, комически остраняющий ситуацию своими репликами.

Мечты Остапа Бендера и мечты героя-повествователя у Довлатова сходны своим гротескным характером и географическим кодом: у одного „игорный особняк в Риге”, у другого - писательский проект в Таллине; у одного заграждение Нила, у другого - политические акции, сотрясающие Европу. Парадоксальным образом мечта о книге контекстуально связывается с „ипподромом - рассадником буржуазных настроений”. Тем самым они окрашиваются авантюрными коннотациями, словно писатель также участвует в ,забеге” и в азартной игре с судьбой.

Дилогия о Бендере является не только очередной панорамой русской жизни, но и своеобразной энциклопедией плутовства, из парадигмы которой невозможно изъять тему игры на скачках. В русской литературе образ ипподрома привлекал многих писателей (ср. Изумруд Александра Ивановича Куприна, Фогобал Владимира Алексеевича Гиляровского). В Двенадизати cmульях эта тема вводится в виде вставной новелы о графе Друцком, которую Остап рассказывает Ипполиту Воробьянинову, перекрашивая его усы:

Графу дали три года. Оказалось, что „Маклер” не орловец, а перекрашенный метис [...] Вот это красочка! Не то что ваши усы!.. (Il'f, Petrov 1991: 59).

В книге Довлатова юбилею таллинского ипподрома целиком посвящен Компромисс второй. Автор отмечает, что заслуженный ипподром представлял собой „жалкое зрелище” с косыми трибунами и запущенным полем, но он был единственным местом, где „в розлив” торговали дешевым портвейном. Здесь еще сохранился „нэпманский” дух наживы:

Фаворита угадать нетрудно. Труднее предусмотреть неожиданное - вспышку резвости у какого-нибудь шелудивого одра. Классные наездники за большие деньги придерживают фаворитов. Умело отстать - это тоже искусство. Это даже труднее, чем победить. [...] Выигрыши достигают иногда ста пятидесяти рублей (Dovlatov 2016a: 11).

Поэтому ассоциации с авантюрной дилогией Ильфа и Петрова могли казаться Довлатову естественными. Слово „буржуазный” в советской печати могло маскироваться словом „внешний”. В повести Ремесло Довлатов пишет:

Эстонскую культуру называют внешней. [...] А ругают внешнюю культуру, я думаю, именно потому, что ее так заметно не хватает гостям эстонской столицы. В Эстонии - нарядные дети. В Эстонии нет бездомных собак. В Эстонии можно увидеть такелажников, пьющих шерри-бренди из крошечных рюмок... (Dovlatov 2016b: 74). 
Ассоциации усиливались и „богемным” характером главного героя, вынужденным скитаться по Союзу в поисках заработка. Но встречается в Компромиссе и более эксплицированный мотив „богатства”. В Компромиссе десятом Довлатов пишет:

За Нарвой пейзаж изменился. Природа выглядела теперь менее беспорядочно. Дома более аккуратно и строго (Dovlatov 2016а: 135).

Мотив „золотой лихорадки” у Ильфа и Петрова имеет среди прочих воплощений и образ затонувших сокровищ. Одна из глав дилогии называется Среди океана стульев, а в главе XXVII Разговор с гольм инженером знаменитый лозунг „лед тронулся” превращается в образ замусоренной реки, напоминающей вышеприведенный пассаж из введения к Компромиссу:

Лед, который тронулся еще в дворницкой [...] измельчал и стаял. Льда уже не было. Была широко разлившаяся вода, которая [...] несла на себе Ипполита Матвеевича, швыряя его из стороны в сторону [...] По реке плыли мусор, нефтяные остатки, пробитые курятники, дохлая рыба [...] плыть против течения бывший предводитель дворянства не имел ни сил, ни желания. Его несло в открытое море приключений (Il'f, Petrov 1997: 172).

У Довлатова метафоры реализуются в сюжеты и мотивы конкретного характера. Так, „затонувшие” сокровища трансформируются в случайно оброненную в морскую глубь вставную челюсть („А там у него золота колов на восемьсот с довеском"), поднятую со дна с риском для жизни - перед надвигающимся штормом - водолазами, якобы занятыми „поиском ценного груза" (Компромисс пятый). Как и приключения Остапа Бендера, авантюра в итоге терпит крах: во время „обмывания” находки ,золотая” челюсть оказывается украдена.

Речной мусор, уже упомянутый Довлатовым метафорически во вступлении, вновь всплывает в Компромиссе восьмом:

Жбанков [...] Произвел звериный, неприличный вопль и рухнул... Поднялся фонтан муаровых брызг. Со дна потревоженной реки всплыли какие-то банки, коряги и мусор (Dovlatov 2016a: 106).

Не только Остап Бендер, но и женские персонажи Ильфа и Петрова имеют больше одного аналога в Компромиссе. Коллективный образ женщин, влюбленных в Эрнста Буша, находит частичное соответствие и в образе подруги героя-повествователя. Так, брошенная и обокраденная мадам Грицацуева вступает в следующий диалог с Бендером:

- Товарищ Бендер! [...]

- Ну что вы терзаетесь, кто вам мешает жить? [...] 
- Сам уехал, а сам спрашивает. А я ждала, ждала, торговлю закрыла.

Все это она произносила с плачем.

- Изменщик, - выговорила она вздрогнув, чтоб тебе лопнуть! [...]

- Обниматься некогда, - сказал он, - прощай любимая! Мы разошлись как в море корабли

(Il'f, Petrov 1991: 182).

В Компромиссе отчасти схожая роль достается Марине, которая ревнует героя-рассказчика, обвиняя его в пьянстве, пытается заплакать „горько и отчаянно” и получает в ответ довольно циничное заявление: „Пока мне хорошо, я здесь, мне надоест, уйду" (Dovlatov 2016а: 36).

Одна из масок автора - служивший в лагерной охране филолог Алиханов (Компромисс шестой), который копирует черты речевой характеристики Остапа в эпизоде посещения мадам Боур (гл. XVI Союз меча и орала в Двенадияати стульях):

- Мадам, - сказал он, - мы счастливы видеть в вашем лице...

Он не знал, кого он счастлив видеть [...] Пришлось начать снова. Изо всех пышных оборотов $[\ldots]$ вертелось в голове только [...] „милостиво повелеть соизволил” (Il'f, Petrov 1997: 140).

У Довлатова галантным хозяином, встречающим неизвестную ему даму-визитера, является сам косноязычно-велеречивый герой:

Затем попытался еще раз, теперь уже штурмом осилить громоздкую фразу: - Чем я обязан, можно сказать, тому неожиданному удовольствию, коего... [...] Чем я обязан неожиданному удовольствию лицезреть? (Dovlatov 2016а: 64).

Помимо вдовы Грицацуевой и аристократки мадам Боур Ильф и Петров создали запоминающийся образ „людоедки” Эллочки Щукиной, ведущей „титаническую борьбу” с целью перещеголять дочь американского миллиардера Вандербилла:

Платье, отороченное собакой, нанесло заносчивой Вандербильдихе первый меткий удар. Потом [...] Эллочка приобрела у домашнего скорняка Фимочки Собак шиншилловый палантин (русский заяц, умерщвленный в Тульской губернии), завела себе голубиную шляпу из аргентинского фетра и перешила [...] пиджак мужа в модный дамский жакет (Il'f, Petrov 1991: 151).

При всем своем эстетизме и амбициях Эллочка отличается минимальным словарным запасом. Отсвет этого персонажа падает на „беспечную” Аллу Мелешко из Компромисса третьего, которая приехала то ли из Саратова, то ли из Двинска в „широкополой шляпе” и в „импортных” сапогах. Она не стесняется сообщить, что Одри Хепберн прислала ей импортный шампунь. Речь ее так же лапидарна: 
- A, - говорю, - здравствуйте. Ну как?

- Гемоглобин - 200.

- Не понял.

- [...] Паршиво, как же еще... (Dovlatov 2016a: 22).

С Эллочкой связан образ „домашнего скорняка” Фимочки Собак, которая сшила „шиншилловый палантин” из „русского зайца” и „слыла культурной девушкой - в ее словаре было около ста восьмидесяти слов", включая слово „гомосексуализм” (Il'f, Petrov 1997: 151).

У Довлатова нет в точности такого персонажа, но сочетание гомосексуализма, космополитизма, портновского мастерства и культурных запросов воплотилось в образе театрального портного Вольдемара Сильда, героя Компромисса седьмого, который во время войны „вешал советских патриотов”, а после войны служил под началом директора театра, „бывшего обер-лейтенанта CC" и гомосексуалиста (Dovlatov 2016а: 80-81). Над культурным уровнем Сильда Довлатов тоже посмеивается, поскольку Сильд смотрит на театральное искусство с точки зрения портного:

- И только на спектаклях моего любимого Вахтанговского театра, - говорит В. Сильд, - я забываю о том, что я модельер, и слежу за развитием пьесы - верный признак того, что костюмеры в этом театре работают безукоризненно (Dovlatov 2016a: 80).

Обширная галерея портретов в дилогии Ильфа и Петрова находит множество соответствий в книге Довлатова. Целый ряд узнаваемых мотивов перенесен на фотографа Жбанкова, одного из спутников героя-повествователя.

В Двенадиати стульях мотив фальши и обмана связан не только с главными героями, но и отчасти - с более респектабельными представителями общества. Так, в сцене запуска новой трамвайной линии появляется кинорежиссер-халтурщик, снимающий псевдо-документальный фильм:

Дышите глубже. Вы взволнованы... Так... Прекрасно. Коля, кончили.

- А трамвай снимать не будете? - спросил Треухов застенчиво.

- Видите ли, - промычал кожаный режиссер, - условия освещения не позволяют. Придется доснять в Москве (Il'f, Petrov 1997: 101).

Аналогичная реплика вложена Довлатовым в уста Жбанкова:

Линда замерла, устремив глаза в пространство.

- Порядок, - сказал Жбанков [...].

- А корова? - удивилась Белла. [...] По-моему, их нужно сфотографировать рядом.

- Корова здесь не поместится, - разъяснил Жбанков [...] Коров в редакции навалом [...]

Вырежу твою Линду и подклею (Dovlatov 2016а: 116). 
Помимо „кожаного режиссера” Жбанков также напоминает пьяницу, эстета, хвастуна и гробовых дел мастера Безенчука в Двенадиати стульях (гл. II Кончина мадам Петуховой):

Хотя дикая рожа и сияла, но сказать он ничего не мог. [...] Нимфа разве товар дает... [...] А я - фирма старая. У меня гроб - огурчик. <...> Тут только Ипполит Матвеевич заметил, что мастер смертельно пьян (Il'f, Petrov 1991: 18).

В Компромиссе восьмом Жбанков кричит, „угрожающе приподнимаясь”:

- Я художник, понял! Художник! Я жену Хрущева фотографировал! Самого Жискара, блядь, д’Эстена! У меня при доме инвалидов выставка была! А ты говоришь - корова!.. - Дурень ты мой, дурень, - любовалась им Белла, - пойдем, киса, я тебя спать уложу... (Dovlatov 2016a: 120).

Жбанков так же шантажирует свое начальство, как инженер Талмудовский в Золотом теленке. Если Талмудовскому казалось, что администрация не выполняет договорных обязательств, он собирал вещи для отъезда: „Квартира - свинюшник, театра нет, оклад [...] Извозчик! Пошел на вокзал” (Il'f, Petrov 1933: 22). Схожим образом ведет себя и Жбанков, когда главный редактор Туронок не спешит выполнять его требования: „сомнения [...] были прекращены вопросом Жбанкова о времени работы кассы взаимопомощи, что являлось скрытой угрозой уйти в запой” (Dovlatov 2016a: 22).

С Безенчуком у Ильфа и Петрова связан макабрический юмор, в частности эпизод торгов с Воробьяниновым за право на похороны тещи (Il'f, Petrov 1997: 57). В Золотом теленке эту тему продолжает посещение учреждения „Геркулес”, где в одной из комнат обнаруживается гроб с надписью „Смерть бюрократизму!”: „Этот гроб [...] носили по праздникам на демонстрациях” (Il'f, Petrov 1933: 251). Схожий юмор можно встретить в Компромиссе одиннадиатом, где герою-повествователю приходится не просто присутствовать на похоронах незнакомого ему видного чиновника, директора телестудии Хуберта Ильвеса, но и произнести о нем „теплую” речь, а позднее даже поделиться с ним собственным галстуком.

Смесь наивной искренности и официозной фальши - важнейший мотив речевой характеристики рядовых героев Ильфа и Петрова. В главе XV Дышите глубже, вы взволнованы! (Двенадцать стульев) Гаврилин произносит речь о запуске трамвая:

Гаврилин начал свою речь хорошо и просто [...] Ободренный приемом, Гаврилин, сам не понимая почему, вдруг заговорил о международном положении (Il'f, Petrov 1997: 130).

В Компромиссе восьмом та же метаморфоза происходит в интервью трудолюбивой эстонской доярки: 
- Записывайте, - сказала Белла, - Коммунистическая партия и ее ленинский Центральный Комитет...

- Все ясно, - говорю, - узнайте, состоит ли она в партии? (Dovlatov 2016а: 116).

Кроме эпизода с недоснятым запуском трамвая в дилогии есть эпизод, связанный с недостроенной магистралью Турксиба. Прибывший на магистраль член правительства принял рапорт от начальника магистрали о досрочном выполнении строительства:

Когда формальность была выполнена, рапорт отдан и принят, два немолодых и несентиментальных человека поцеловались (Il'f, Petrov 1933: 366).

Схожим образом в Компромиссе восьмом происходит бюрократическое чудо обратного течения времени, когда журналисты приезжают в колхоз, чтобы помочь составить благодарственную телеграмму от лица награжденной за героический труд Линды Пейпс генсеку Леониду Брежневу, но, закончив интервью, узнают, что ответная телеграмма от товарища Брежнева пришла раньше, чем была составлена телеграмма Линды Пейпс:

- Что же пишет товарищ Брежнев?

- Поздравляет... Благодарит за достигнутые успехи... Желает личного счастья... (Dovlatov 2016a: 118-119).

Во вступительной статье „От авторов” к Золотому теленку Ильф и Петров отстаивают свое право на высмеивание официозной фальши и штампа:

Сатира не может быть смешной, - сказал строгий товарищ и, подхватив под руку какого-то кустаря-баптиста, которого он принял за стопроцентного пролетария, повел его к себе на квартиру. Повел описывать скучными словами, повел вставлять в шеститомный роман под названием: A паразиты никогда! (Il'f, Petrov 1933: 13).

Чувство официозной скуки ненавистно и автору Компромисса:

- Тебя Цехановский разыскивает. Хочет долг вернуть. [...] Деньги получил за книгу.

- Караван уходит в небо? [...] - Я оглядел заваленные газетами столы. Ощутил запах табачного дыма и клея. Испытал такую острую скуку и горечь, что даже атмосфера больницы уже не пугала меня (Dovlatov 2016a: 36).

Высмеивают Ильф и Петров и цензуру. В Золотом теленке (глава третья Снова кризис жанра) сочинитель ребусов Синицкий пытается написать идеологически выдержанную шараду для слова „индустриализация”, но лишь демонстрирует свою отсталость и политическую неграмотность. Дочь Зося и Корейко его поправляют: 
- Что ты тут написал? [...] „Четвертый слог поможет бог узнать, что это есть предлог”. [...] Синицкий ахнул. Крича: „Где бог, где? Там нет бога” [...]

- Есть бог, - промолвил он печально. [...]

- А ты вместо „бог” поставь „рок”, - сказала Зося. [...]

- Это тоже мистика. [...] Я еще третьим слогом поставил „кац” и написал так: „А третий слог, досуг имея, узнает всяк фамилию еврея". Не взяли эту шараду. [...]

- Этот ребус трудненько будет разгадать [...] Придется вам посидеть над ним!

- Придется, придется, - ответил Корейко с усмешкой, - [...] „В борьбе обретешь ты право свое”? [...] Это эсеровский лозунг. Для печати не годится.

- Ax ты боже мой! - застонал старик. - Царица небесная! Опять маху дал. (Il'f, Petrov 1933: 130).

Тема цензурных ограничений и препон возникает у Довлатова уже в Компромиссе первом, где герой-повествователь точно так же наивно нарушает идеологические конвенции, раз за разом получая разнос от редактора за неправильное перечисление стран - участниц научной конференции:

Демократические страны - вперед! Затем - нейтральные государства. И, наконец, участники блока [...] Венгрию - на третье место! Там был путч... Политическая близорукость! Нравственный инфантилизм! (Dovlatov 2016a: 9-10).

Примечательно, что Остап Бендер также проявляет себя как автор. Он создает киносценарий Шея и получает за него гонорар, но меньше, чем ожидал:

- Вы говорите с толком. Что вам нужно [...] Короче, сколько вам следует? [...]

- Девятьсот рублей...

- Триста... получите, уходите. [...] Вы украли у меня лишних полторы минуты (Il'f, Petrov 1933: 311).

Сатирический и карнавально-амбивалентный взгляд на реалии советской жизни характерен как для Ильфа и Петрова, так и для Довлатова. Отношение последнего к собственному ремеслу - эпатирующе-презрительное. Не случайно Компромисс двенадиатый заканчивается диалогом со своеобразным alter ego:

Мой брат, у которого две судимости (одна - за непредумышленное убийство), часто говорит:

- Займись каким-нибудь полезным делом. Как тебе не стыдно?

- Тоже мне, учитель нашелся!

- Я всего лишь убил человека, - говорит мой брат, - и пытался сжечь его труп. А ты?! (Dovlatov 2016a: 219).

Журналистская работа - это погоня за деньгами, в которой есть своя „правда”, но далекая от истинного искусства. Путь к искусству можно прой- 
ти только двигаясь в обратном направлении - от официозной фальши к подлинной жизни и заключенному в ней искусству.

Герой-повествователь Довлатова способен на это, как и герой Ильфа и Петрова. Он - герой пути, а значит не окончательно пропащий. Не зря Остап Бендер заявляет в Золотом теленке: „Я, конечно, не херувим. [...] Но я чту Уголовный кодекс. Это моя слабость" (Il'f, Petrov 1933: 43). Довлатов подхватывает и эту дихотомию, заменив херувима ангелом в Компромиссе третьем: „В этой повести нет ангелов и нет злодеев [...] Да и в жизни их не существует" (Dovlatov 2016a: 14).

Как можно было убедиться, в книге Компромисс, созданной в период явно обозначенного интереса Довлатова к дилогии Ильфа и Петрова (письмо к Людмиле Яковлевне Штерн) имеется обширная сеть персонажей, мотивов, лексических перекличек, идейных коллизий, прямо или косвенно связанных с литературным наследием авторов Двенадиати стульев и Золотого телен$\kappa a$. Единственное, чего в Компромиссе нет, так это единой фабулы, охватывающей всю книгу, но эта проблема успешно решается на уровне отдельных „Компромиссов”.

Разница, конечно, и в том, что романы Ильфа и Петрова создавались в эпоху, которая рассматривалась авторами как переход к социализму, тогда как Довлатов не имел никаких иллюзий на счет социализма, и его сочувствие вызывали рудименты буржуазной культуры, еще сохранявшиеся в Эстонии 1970-х годов.

\section{Библиография}

Ânovskaâ, Lidiâ. Počemu vy pišete smešno? Moskva, Nauka, 1969.

Čudakova, Mariètta, Aleksandr Čudakov. „Sovremennaâ povest' i ûmor”. Novyj mir, nr 7, 1967.

Dovlatov, Sergej. Maloizvestnyj Dovlatov. Sankt-Peterburg, Azbuka, 2017.

Dovlatov, Sergej. Kompromiss. Sankt-Peterburg, Azbuka, 2016a.

Dovlatov, Sergej. Remeslo. Sankt-Peterburg, Azbuka, 2016b.

Dovlatov, Sergej. „Sergej Dovlatov: tvorčestvo, ličnost', sud'ba: itogi Pervoj meždunarodnoj konferencii «Dovlatovskie čteniâ»”. Sankt-Peterburg, Zvezda, 1999.

Dovlatov, Sergej. Sobranie sočinenij: v 4 t. T. 4. Sankt-Peterburg, Azbuka, 2003.

Efimov, Igor', Sergej Dovlatov. Èpistolârnyj roman. Moskva, Zaharov, 2001.

Falikova, Natal'â. K. Vaginov kak sovetskij pisatel': problema novoj identičnosti v avantûrnom romane „Bambočada”. Materialy meždunarodnoj konferencii molodyh filologov. Tartu, 27-29 aprelâ 2018 g., 2018.

Galanov, Boris. Il'â Il'fi Evgenij Petrov. Moskva, Sovetskij pisatel', 1961.

Gandlevskij, Sergej. „Strannye sbliženiâ”. Inostrannaâ literatura, nr 10, 2004.

Gudman, Walter. „O knige S. Dovlatova «Kompromiss»”. Zvezda, nr 3, 1994.

Il'f, Il'â. Zapisnye knižki. Moskva, Sovetskij pisatel', 1957.

Il'f, Il'â, Evgenij Petrov. Dvenadcat'stul'ev. Moskva, Vagrius, 1997. 
Il'f, Il'â, Evgenij Petrov. Dvenadcat'stul'ev. Zolotoj telenok. Riga, Trans izdevejs, 1991.

Il'f, Il'â, Evgenij Petrov. Zolotoj telenok. Moskva, Sovetskaâ literatura, 1933.

Odesskij, Mihail, David Fel'dman. Miry I.A. Il'fa i E.P. Petrova. Očerki verbalizirovannoj povsednevnosti. Moskva, Rossijskij gosudarstvennyj gumanitarnyj universitet, 2015.

Rosenberg, Karen. „Of Compromise and Corruption”. The Nation, CCXXXVII (November 5), 1983.

Ŝeglov, Ûrij. Dvenadcat'stul'ev. Moskva, Panorama, 1995.

Semenenko, Aleksej. „L. Pejps kak zerkalo sovetskoj dejstvitel'nosti, ili o metode Sergeâ Dovlatova". Russkaâ filologiâ. 10: Sbornik naučnyh rabot molodyh filologov. Red. Tat'âna Stepaniŝeva, Ol'ga Palikova. Tartu, Ülikooli kirjastus, 1999.

Šklovskij, Viktor. Gamburgskij sčet. Moskva, Sovetskij pisatel', 1990.

Tomaševskij, Boris. Teoriâ literatury: Poètika. Leningrad, Gosizdat, 1925. 